特集 I /净化槽による地域環境保全とその可能性

\title{
浄化槽の現状と展望
}

\section{Present Stage and Future of Onsite Wastewater Systems \\ 一一特集にあたって——}

勝 矢 淳 雄 $*$

\section{1. はじめに}

生活排水による河川, 湖沼の污濁は社会的に注目を あびている．生活排水対策の基本である公共下水道も 大都市の人口稠密な地域に打いては整備も進んできた が，地方中小都市では財政的事情ああり現在まであま り進渉はみられず，今後む多くを期待することは困難 である、乙のため, 従来の公共下水道とは規模, 方式 のみならず, その整備の思想を屯異にする各㮔の生活 排水対策が検討されだしている，乙の一つとして，浄 化槽が技術的水準の向上とともに水環境保全施設の視 点から新たな見な扎しがなされだしてきた，そてで， 浄化槽の現状と課題を水質污濁防止の観点から考察を 加えてみる.

\section{2. 浄化槽の現状}

従来, 浄化槽は公共下水道未整備地域に打いて, 便 所を水洗化するために建築物に付随した施設としての 位置づけがなされ, 公共下水道整備までの一時的なむ のと見做されてきた. このため, 公共用水域などの水 質污濁防止の観点からでなく，し尿の衛生的処理，伝 染病の予防などに重点が执かれていた。

一方，健康で文化的な生活を保持するための快適な 生活環境づくりの第一歩として, 便所の水洗化に対す る住民の要望は強く，FRP（強化プラスチック）によ る大量生産と低価格化は, 住宅建設の波とと屯に浄化 槽を急速に普及させた。 最近の 20 年間をみても, 下水 道と浄化槽による水洗化人口はほぼ同様に増加をして おり, 浄化槽人口の一部が公共下水道へ移行している ことを考えれば，浄化槽は実質的にはさらに高い伸び 率を示していることとなる（図-1）.今後もこの傾向 は続くとみられ, 公共下水道未整備の地方中小都市に おいて暮しの質の向上への期待から浄化槽の増加傾向

*京都産業大学教授 Atsuo KATSUYA

「環境技術」編集実行委員

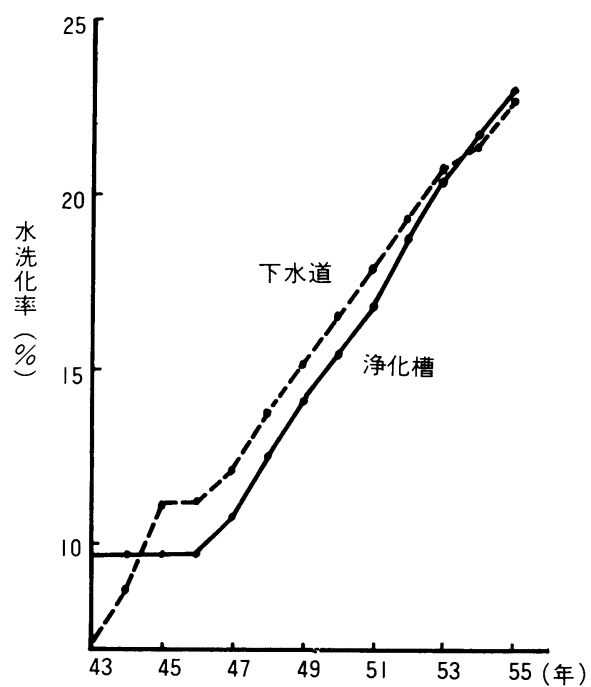

図-1 総人口に対する下水道执よび浄化槽による水洗 化人口の比率（厚生省調べ)

はさらに強くなるとみられる，浄化槽を設置基数でみ れば,昭和 35 年 2 月の 12 万基から昭和 56 年度末で約 400 万基となり，最近は毎年30〜 40万基の増加をみている. ところが, 浄化槽は公共下水道整備までのつなぎとし て，かつ民間資本で普及が進められたため，行政的対 応が不十分なままに現在に至り多くの問題を生ずるよ うになった。

その第 1 は, 設置される净化槽はし尿のみの単独処 理が大半を占め, 台所, 風呂などからの雑排水は無処 理で放流されていることである. 昭和58年の前半期に おいても，99\%以上が単独処理の一般住宅用浄化槽で あった．河川の水質污濁や湖沼など閉鎖系水域におけ る富栄養化に生活雑排水が占める污濁負荷が相対的に その比率を増大しだし，生活排水対策が重要となって きているにもかかわらず，単独処理浄化槽は水環境保 全のためには全く寄与していないわけである(図-2).

これは, 浄化槽が放流水質を規制する性能基準のみ ならず, 構造, 処理方式についてまでを構造基準で規 
〔全国主要16河川の平均〕

〔大和川〕

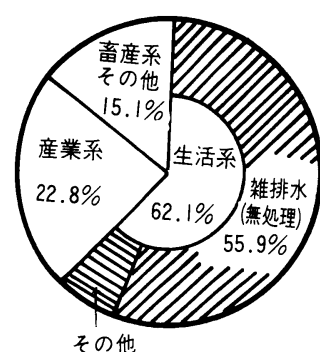

$6.2 \%$

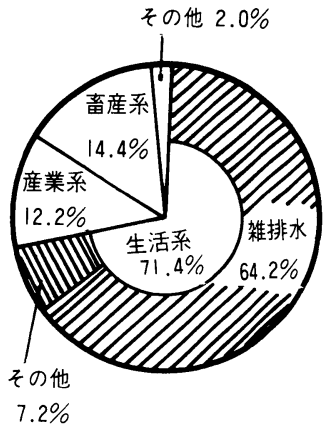

$7.2 \%$

図-2 発生源別BO D排出負荷の比率(昭和55年度)

制されており，乙てで家庭用の小型の浄化槽ではし尿 之雑排水を併せて処理する合併処理方式が事実上認め られていないととによる。構造が規制されているとと により, 技術の発展が著しく阻害されていることは, 今後検討の余地が多分にある.

浄化槽はし尿のみの単独処理である限り, 公共下水 道やし尿処理施設と同程度の高度な処理をしたとして あ, 水質污濁負荷の增大をあたらすととになり, 水環 境保全の観点からは意義は少ないわけである。

第 2 は, 構造基準が決められているにもかかわらず, 構造の不備や維持管理の不徹底などの種々の条件のた めに放流水質が基準値を上回っている場合が多く、さ らには悪臭, 衛生害虫の発生により近隣に迷惑をかけ ているととあある点である. 維持管理基準の遵守と不 良浄化槽の解消のために始められた浄化槽の法定検查 において, 昭和 57 年度の検查数 13 万基のうち「適正」 とされたすのは55\%にすぎず，他は何らかの問題が指 摘されている. 現在のとてろ比較的規模の大きい浄化 槽しか検查が行なわれていないてとからみると, 維持 管理が不徹底である小型の浄化槽では適正でないあの の比率はさらに増加すると判断でき, 小型の家庭用净 化槽の放流水基準がBODで $90 \mathrm{mg} / \ell$ であるととと併 せみると, 浄化槽が水質污濁の一因となっているてと は否定しがたいところである。乙れは単に技術的な問 題のみならず, 浄化槽の維持管理が民間にまかせられ ているととと, てれに対する行政側の十分な指導体制 が欠如していたてとにあ原因がある。

第 3 には, 浄化槽から発生する污泥は浄化槽の延び により年々増加し, 昭和55年度で 2.3 万k $\ell /$ 日となっ ているが, 行政側の対応の遅れあありその処理が不十 分である点である．乙れは何も净化槽に限らずし尿処 理に扔いても同様の状態であり，一概に浄化槽のみを

問題視することは出来ないが, 公共下水道の整備のみ に期待をかけ，し尿処理打よび浄化槽への対応に遅れ を生じた結果といえる。昭和55年度において，科学的 にみてあその合理性についてまだ明確でない海洋投棄 で処理された浄化槽污泥は全体の $25 \%$ に当る約 6 千 $\mathrm{kl}$ /日である.ちなみに, 海洋投棄で処理されたし尿は約

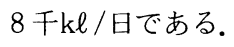

以上の様な現状は，生活排水による水質污濁を防止 する施設として浄化槽を位置づけることは困難である と屯考えられるが, 現在, 浄化槽に扣ける技術革新は 下水道を上回るほどの進展をみせており，乙れは浄化 槽に扔いて発展した技術が下水道に扔いてあ取り入れ られているてとからあ明らかである。すすなわち, 水処 理技術としては浄化槽も下水道む基本的には変るわけ ではないことから当然のことである。浄化槽に扔ける 各㮔の問題は技術的な側面より行政的な側面にネック があるわけであり, 浄化槽を水環境の保全のための施 設として位置づけるためには，乙の行政的側面におけ る改善がより重要であり先決であるといえる.

\section{3. 浄化槽発展のための課題}

公共下水道の整備が財政的にあ時間的にも地方中小 都市に扔いて, 多くを期待するてとが困難である以上, 水処理技術としては同じである浄化槽を公共下水道を 補完する施設として有効们利用し, 発展させることが 出来机ば，多くの面で意義が大である，たとえば，浄 化槽が全て民間資金で設置され，維持管理がなされて いるととから, 行政として財政的負担の軽減に役立つ わけであり, 行政改革の方向にあ一致する. 従来, 民 間ベースで行なわれていたため, 生活基盤施設として 浄化槽を位置づげることをしなかったことに多くの問 題点を生じた原因がある，そこで今後，净化槽の発展 を期するためには以下の様な点について検討するてと が必須である。

第 1 は, し尿と雑排水を併せて処理する合併処理浄 化槽について, さらに技術水準の向上を計ることであ る. 小規模の施設になるほど要求される条件は笽しく, 水量・水質の变動に強く, 維持管理が容易であること などが要求される，現在の小型合併処理浄化槽は試験 段階を脱した状態と判断できるが，今後さらに合理的， かつ経済的なシステムへの技術的側面からの発展は重 要であり,また困難なととではないと考えられる.

第 2 は, 浄化槽の設置について計画性をむたせるこ とである. 従来の浄化槽は住民の水洗化への要望の高 
い大都市周辺地域に偏っているため, 公共下水道の進 渉により廃止され，二重投資の傾向が強くあった。今 後は公共下水道の計画的整備を配慮しながら, 下水道 未整備地域を中心にして, 浄化槽モデル地域などを設 定・推進し, 積極的に浄化槽設置を行政的にも援助し 民間資本を有効に活用していくことも検討すべきであ る.

このためには, 地域の人文, 社会, 経済的な側面ま で含めて地域の実情を把握し, 地域特性に最も適した 処理規模, 方式などの選択之指導が必要である. たと えば, 従来通りのし尿のみの単独処理で十分な地域も あれば, し尿と雑排水の合併処理を必要とする地域, あるいは戸別より共同処理がより適する場合あある.

第 3 は, 維持管理体制の整備である. 維持管理の容 易な浄化槽の開発は重要であるとしても, 現状におけ る維持管理体制の不備および民間業界の資質向上に行 政が無関心であったことは, 不良浄化槽や無届け浄化 槽による水質污濁を引き起した元凶の一つといえる. 今後も浄化槽の維持管理を民間業界にまかせるならば, 民間業界自らは勿論のこと, 行政, 研杂者などあ一致 協力して業界の技術水準の向上に努めるてとが大切で ある。

第 4 は, 污泥処理体制の整備である。乙れは浄化槽 に限らず, タメマスなどにおいても問題となってきて おり,さらに将来, 小規模下水道の整備に扔いても污 泥処理は重要な課題であり, 污泥処理に関する総合的 な検討が必要といえる。

その他, 無届け浄化槽や不良净化槽を如何にして一 掃するかなどの問題ああり，全ての浄化槽が水質的に あ良好な状態を達成しえなければ，浄化槽に対する社 会的信頼を取り戻すことは困難であり，また将来の発 展も望みえないのは明らかである。

\section{4. まとめ}

浄化槽における問題点などを指摘したが, てれらの 全ての原因は浄化槽を社会的に認知しようとしなかっ た，行政などの姿勢に寄るところが大きい．日本の社 会の特性として，画一的に一方向しか認めない傾向が 強く, 多様な思考, 方策は混乱の基として嫌う面があ った。しかしながら, 現在における経済事情の逼迫を 屯考慮するとき, 総合的なバランスを取りながら種々 の方策を適切に推進することは不可欠であり，鿇化槽 にみられる民間の自発的な活力を十二分にいかし，そ の健全な発展を期すれば, 公共下水道とあいまってよ
り早く水環境の保全と, 総水洗化による快適な生活環 境を実現しうることが可能となる。

净化槽法の成立が, 行政。民間業界, 研究者および 住民がそれぞれの立場において，浄化槽のよりよい発 展のために協力しあう契機となることを強く期待する ものである.

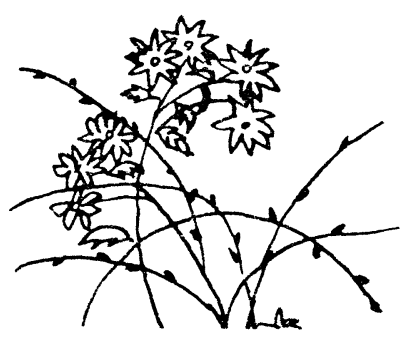

